\title{
A Rank Order of Accurate Use at the \\ Syntax-Pragmatics Interface: \\ Evidence from French and Spanish L2 Acquisition
}

Nicola Work (Dayton, Ohio)

\begin{abstract}
In an attempt to investigate the vulnerability of the syntax-pragmatics interface and to shed light on the acquisition of subjects and objects in two different languages, namely the $[+$ null subject] language Spanish and the [-null subject] language French, this article presents evidence from a crossectional and crosslinguistic university classroom study. The experiment investigated various linguistic structures whose use is determined by information structure: preverbal subjects, null subjects, postverbal subjects and in situ objects with preverbal subjects, in situ objects with null subjects, Clitic Left Dislocations (CLLD) with null and with postverbal subjects in Spanish; subject clitics, subject dislocations, c'est clefts and in situ objects with subject clitics, in situ objects with subject dislocations, CLLDs with subject clefts and with subject dislocations in French. 76 English learners of French, 67 English learners of Spanish as well as 5 native French controls and 8 native Spanish controls participated in the study. Results of the rating task evaluating learners' pragmatic intuitions indicate a crosslinguistic rank order of acquisition.
\end{abstract}

\section{$1 \quad$ Introduction}

\subsection{Interface Hypothesis}

Researchers in language acquisition have for quite some time been interested in interfaces, which can be defined as "loci of information integration across modules of language and/or external cognitive domains" (Rothman 2012: 3). Every speaker has a grammar consisting of several modules (syntax, semantics, phonology) as well as a pragmatic system at their disposal. This interaction among these different domains of language modules with the pragmatic system (i. e. the interface) can cause difficulties for learners (cf. Bos/Hollebrandse/Sleeman 2004). The term Interface Hypothesis (IH) first appeared in Sorace and Filiaci's (2006) study even though the phenomena associated with it had been under investigation before. This early original version of the $\mathrm{IH}$ predicts that properties at linguistic interfaces may be more vulnerable to errors, fossilization and incomplete acquisition than intra-module properties (cf. Sorace 2003). That means, structures that involve an interface between syntax and other cognitive domains may cause optionality and instability whereas structures that require only syn-

Linguistik online 70, 1/15 - http://dx.doi.org/10.13092/lo.70.1750

CC by 3.0 
tactic computations are acquired completely and remain stable. This version, early on extended to bilingual L1 acquisition and early L1 attrition, was later criticized, even by Sorace herself, as being a good starting point, but too broad. The main criticisms were the difficulty in identifying structures that are sensitive to only syntactic constraints as well as structures that are only sensitive to one interface condition (cf. Sorace 2011). Since its original formulation, this version of the IH encouraged a lot of research on the syntax-pragmatics interface in different situations of language acquisition, mainly in monolingual and bilingual L1 acquisition. A more recent and more specific version of the IH posits that external interfaces (i. e. where syntax interfaces with other cognitive domains, such as the syntax-pragmatics interface) result in greater difficulties than internal interfaces (where only formal properties of the grammar are implicated) (cf. Sorace/Filiaci 2006; Sorace/Serratrice 2009; Tsimpli/Sorace 2006). A subsequent substantial body of research in a variety of different situations of language acquisition supports the claims that the syntax-pragmatics interface is a major source of difficulty, causing delays, failure, indeterminacy and optionality even at near-native levels of acquisition. This has been found for advanced L2 learners who are not near-native (e. g. cf. Hertel 2003; Lozano 2006); L2 learners of lower proficiency still in the course of L2 development (e. g. cf. Belletti/Leonini 2004; Dominguez 2007; Dominguez/Arche 2008; Hertel 2003; Montrul/Rodríguez Louro 2006; Work 2010); L1 acquirers (e. g. cf. Hughes/Allen 2006; Paradis/Navarro 2003; Schaeffer 2000; Tedeschi 2009); simultaneous bilingual acquirers (e. g. cf. Argyri/Sorace 2007; Hulk/Müller 2000; Müller/Hulk 2001; Paradis/Navarro 2003; Pinto 2006; Serratrice/Sorace/Paoli 2004); heritage language acquirers (cf. Montrul 2004; Montrul/Louro 2006); and cases of L1 attrition (e. g. cf. Tsimpli et. al. 2004). Even though the IH was originally formulated to include only three different domains of language acquisition, namely simultaneous L1 acquisition, early L1 attrition and near-native L2 ultimate attainment, and specifically excluded L2 learners in the course of development, White (2011) concludes that "results from several of these studies suggest that the problems experienced by steady state near-native L2 speakers do not arrive out of the blue; rather, they show up during the course of language acquisition and during language loss, in younger and older learners" (cf. ibid.: 578). Thus, a study of the syntax-pragmatics interface during various stages of L2 acquisition might prove to be fruitful in order to be able to provide useful information for L2 acquisition researchers in terms of acquisition at the syntax-pragmatics interface.

\subsection{Information Structure}

Closely related to the syntax-pragmatics interface and its correlated syntactic structures are the concepts of topic and focus. Unfortunately, the terms topic and focus have many different, often contradictory definitions. The notions of topic and focus adopted in this paper roughly follow the given-new distinction. Thus, the term topic refers to the point of departure of a sentence: what the sentence is about, the information that is known by a speaker and listener, what is given (cf. Contreras 1976; Erteschik-Shir 2007; Gundel 1988; Halliday 1967, among others). Focus, in contrast, entails the informative part of a sentence: the emphasis or new information (cf. Halliday 1967; Vallduví/Engdahl 1998, among others). Despite the fact that the discourse notions of topic and focus seem quite general and universal, their linguistic mapping varies from language to language. Crosslinguistically, this information is conveyed by aspects of prosody, by special grammatical markers, in the form of syntactic constituents, 
in the position and ordering of such constituents in the sentence, in the form of complex grammatical constructions, and in certain choices between related lexical items. English and German, for example, are so-called intonation languages and hence use intonation to mark information structure. Yet these languages also use many syntactic mechanisms like Topicalization, Focus Preposing, clefts, and passives to mark information structure. Due to the less flexible character of accentuation in the Romance languages, mechanisms other than intonation are typically at work. In general, Romance languages resort to word order variation as opposed to intonation to express information structure (cf. Work 2010).

\subsection{Argument realization in Spanish and French}

Subject and object realization in Spanish and French are closely tied to information structure, which determines the syntactic construction a speaker chooses in a given sentence. Spanish has several ways in which a subject can be expressed depending on its discourse function. Overtly expressed preverbal subjects in the form of a lexical NP or a tonic pronoun are discourse-new or contrastive topics, as seen in (1) below:

Hoy no fui a trabajar. Pepe / él / *Ø pensó que estaba enferma.

Today no went-1Sg to work. Pepe / he-Tonic-3Sg / * Ø thought-3Sg that was1 Sg sick.

Today I did not go to work. Pepe/he thought I was sick.

(Montrul 2004: 176)

Postverbal subjects in Spanish are generally focal because they represent the focus, the new information, as can be seen in (2) below:

$$
\begin{aligned}
& \text { Q: ¿Quién compró el coche? } \\
& \text { Who bought-3Sg the car? } \\
& \text { 'Who bought the car?' } \\
& \text { A: Compró el coche María. } \\
& \text { Bought-3Sg the car María. } \\
& \text { 'MARÍA bought the car.' } \\
& \text { (Zagona 2002: 215) }
\end{aligned}
$$

Spanish overt subjects can also be dislocated to the left or right periphery of the sentence and are generally interpreted as non-focal.

$$
\begin{aligned}
& \text { Es un buen tío, tu hermano. } \\
& \text { Is-3Sg a nice uncle, your brother. } \\
& \text { 'He's a nice guy, your brother.' } \\
& \text { (Casielles-Suárez 2004: 68) }
\end{aligned}
$$

Finally, Spanish, a [+ null subject] language, allows subjects to be null, which are interpreted as discourse-old, active topics.

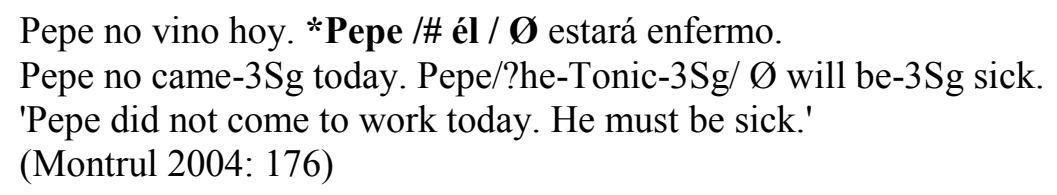

Subject realization in French, a [- null subject] language, differs considerably from that in Spanish in that all subjects have to be overtly expressed and postverbal subjects do not exist. Non-active or discourse-new topics are expressed through a nominal constituent in French. 
(5)

Jean a pris le train.

Jean has-3Sg taken the train.

'Jean took the train.'

(Ferdinand 2002: 50)

Furthermore, active or discourse-old topics are generally expressed through a weak clitic pronoun as is exemplified in (6).

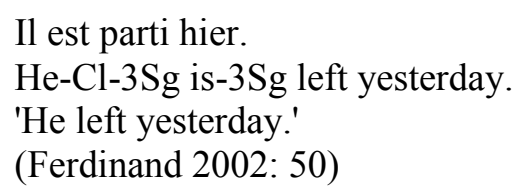

Subjects can also be expressed by means of a cleft, a matrix clause introduced by c'est and an NP or a tonic pronoun, followed by a subordinate clause with the relative pronoun qui. These clefted subjects are interpreted as focal. In situ focal constructions do not exist in French.

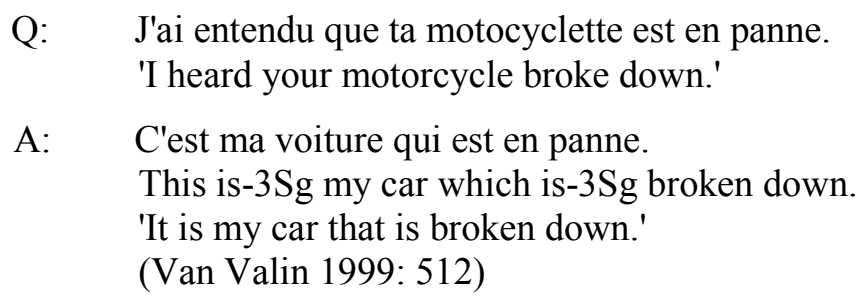

A: $\quad$ 'est ma voiture qui est en panne.

This is-3Sg my car which is-3Sg broken down.

'It is my car that is broken down.'

(Van Valin 1999: 512)

Subjects can also be dislocated to the right or left periphery of a sentence. They are topical in nature.

Moi, je suis contente [...].

I-Tonic-1Sg, I-Cl-1Sg am-1Sg happy.

'I am happy.'

Oui, il est gentil, Monsieur X.

Yes, he-Cl-3Sg is-3Sg nice, Mister X.

'Yes, he is nice, Mister X.'

(Ashby 1988: 204)

Interestingly, French is becoming more and more a topic prominent language (cf. Antes 1995). As a result, speakers increasingly stress the topics of their sentences, generally by employing dislocations instead of using simple subjects (cf. Sleeman 2004).

Subject realization in English differs from that in Spanish and French. Preverbal lexical NPs can refer to discourse-new or contrastive topics like in Spanish or French, but also to discourse-old elements. Since English is a [-null subject] language, discourse-old, active topics cannot be expressed by null subjects, but are rather expressed by a full pronoun. In general, the focus position in English is sentence-final. Since in English subjects cannot occur postverbally, like in Spanish, other mechanisms are employed to mark their focal nature. These include prosodic marking, but also the use of passives, which can place the subject at the active end of the sentence and clefts. If prosody is the marking of choice, a preverbal focal subject is intonationally prominent in English, a strategy that does not exist in French and Spanish.

Below is a summary and comparison of subject realization in French and Spanish paralleled with the learners' L1 English. 


\begin{tabular}{|l|l|l|l|}
\hline & Spanish & French & English \\
\hline $\begin{array}{l}\text { Discourse-new top- } \\
\text { ic; contrastive topic }\end{array}$ & Preverbal subject & $\begin{array}{l}\text { NP; } \\
\text { Dislocated subject }\end{array}$ & NP \\
\hline Discourse-old topic & Null subject & $\begin{array}{l}\text { Clitic; } \\
\text { (Dislocated subject) }\end{array}$ & Pronoun \\
\hline Focus & Postverbal subject & $\begin{array}{l}\text { Clefted subject (c'est } \\
\text { cleft) }\end{array}$ & $\begin{array}{l}\text { Preverbal subject; } \\
\text { Prosody }\end{array}$ \\
\hline
\end{tabular}

Tab. 1: Summary of subject realization in Spanish, French and English.

Object realization in Spanish and French is very similar. Generally, both languages have various ways to express objects depending on their discourse role in the sentence. In Spanish, objects can be expressed by a lexical NP in canonical (in situ) position after the verb, which is the unmarked position for objects in SVO languages.

$$
\begin{aligned}
& \text { Mariano mandó una carta a mis amigos. } \\
& \text { Mariano sent-3Sg a letter to my friends. } \\
& \text { 'Mariano sent a letter to my friends.' } \\
& \text { (Montrul 2004: 184) }
\end{aligned}
$$

An object in its postverbal position is focal and represents the new information in the sentence. Spanish objects can also be expressed by a preverbal object clitic as exemplified in (11) below.

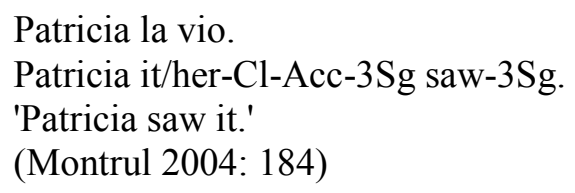

These preverbal clitics with the canonical object position remaining empty are discourse-old topics; just like null subjects are in Spanish.

Finally, objects can be expressed by means of a dislocation structure where the object is put in the left or right periphery, generally with a resumptive clitic pronoun in clitic position. When the object is in the left periphery, it is called Clitic Left Dislocation (CLLD).

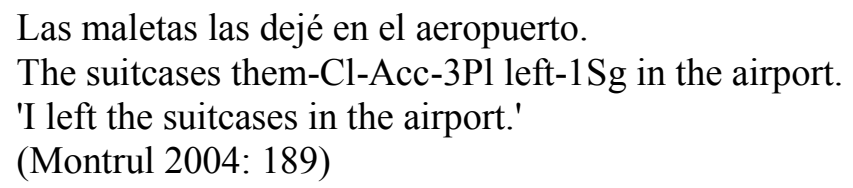

These left-dislocated objects are non-focal and can either be contrastive or discourse-new.

In French, similar to Spanish, objects can be expressed by lexical NPs in postverbal (i. e. canonical) position.

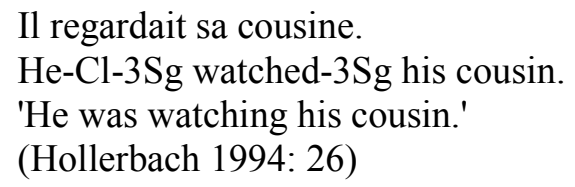

These postverbal lexical objects have the same discourse interpretation as in Spanish, namely they are focal, representing the new and informative part of the sentence.

French also allows preverbal object clitics where the canonical (postverbal) object position remains empty. 


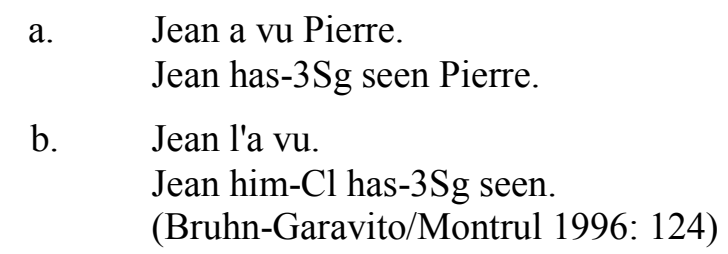

Just like in Spanish, preverbal object clitics are topical and express discourse-old information. Finally, object arguments can also be dislocated to the left or the right periphery of the sentence with a resumptive object clitic in preverbal position.

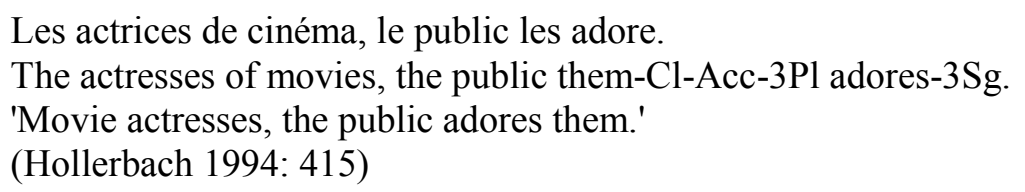

These CLLDs are non-focal and can be contrastive or discourse-new.

Object realization in English has more in common with Spanish and French than is the case with subject realization. In the same way that a subject tends to be topical in SVO languages like English, French and Spanish, an object in its unmarked, postverbal position tends to be focal. Similar to Spanish and French, English discourse-old topics are expressed by pronouns. In Spanish and French, these pronouns are preverbal clitics whereas in English, they are expressed by tonic pronouns in postverbal position. Dislocated objects with a resumptive clitic are non-focal in Spanish and French and can either be contrastive or discourse-new. This is similar to English dislocation structures; however, instead of a resumptive preverbal clitic like in the Romance languages, a resumptive pronoun in postverbal position is used. Even though the syntax of CLLD and English left-dislocation is different, in both cases the interpretation of the dislocated element is similar.

Object realization according to their discourse functions in Spanish and French with comparison to English are summarized below:

\begin{tabular}{|l|l|l|l|}
\hline & Spanish & French & English \\
\hline Discourse-old topic & Preverbal clitic & Preverbal clitic & Postverbal pronoun \\
\hline $\begin{array}{l}\text { Discourse-new } \\
\text { topic; } \\
\text { Contrastive topic }\end{array}$ & CLLD & CLLD & $\begin{array}{l}\text { Left Dislocation/ } \\
\text { Topicalization }\end{array}$ \\
\hline Focus & Postverbal NP & Postverbal NP & Postverbal NP \\
\hline
\end{tabular}

Tab. 2: Summary of object realization in Spanish, French and English.

\section{The Study}

The original purpose of this study (Work 2010) was to investigate argument realization in two different languages, French, a [- null subject] language, and Spanish, a [+ null subject] language. Subject and object realization in these two languages are closely tied to the syntaxpragmatics interface since speakers of these languages have to map universal pragmatic principles onto language-specific structures, selecting only those options syntactically possible in the target language. Integrating syntactic information with the appropriate discourse framework has been shown to cause difficulties for all learners (L1, 2L1, L2, young and old learners). To this end, data was collected to see whether the syntax-pragmatics interface is indeed 
vulnerable and structures at the interface difficult to acquire (see $\mathrm{IH}$ ). Even though, Sorace (2011: 9) emphasizes that the IH should solely be applied to the level of near-native L2 proficiency, this study investigated learners across different proficiency levels. Sorace's contention is that the IH is most relevant to ultimate attainment, but can certainly make developmental predictions. In line with several other researchers (e. g. cf. Lardiere 2011; Slabakova/Kempchinsky/Rothman 2012; White 2011), it is assumed here that IH can and should be applied to developmental data. "There is no a priori reason why learners still in the process of L2 acquisition should not experience similar interface problems to those experienced by bilingual children in the course of their language development, an area that is encompassed by the IH" (White 2011: 109). Furthermore, the study wanted to investigate the syntaxpragmatics interface in more detail seeking to answer the following research questions: (1) Is the vulnerability due to the interface itself or due to the different syntax-discourse mappings in Spanish and French? (2) So particular syntax and discourse features affect the instability? (3) Does syntactic competence precede discourse competence in language acquisition? (4) Is there improvement across proficiency levels?

To this end, three syntax-pragmatics interface structures were tested in detail in French and Spanish respectively: subjects that represent discourse-old topics (null subjects in Spanish, subject dislocation in French), subjects that represent focus (postverbal subjects in Spanish and c'est clefts in French) and objects that represent topics (CLLD constructions in both Spanish and French). Data was collected from 156 college-level informants in the two languages during the Winter semester in 2007 at Wayne State University. Based on the results of an independent proficiency test modeled after those by the University of Wisconsin, learners were grouped into three proficiency levels. The 81 French subjects were divided into 27 lowintermediate, 32 high-intermediate, and 17 advanced English learners of French as well as 5 native speakers of French. The 75 Spanish subjects were divided into 26 low-intermediate, 25 high-intermediate, and 16 advanced English learners of Spanish as well as 8 native speakers of Spanish. The participants were all university students with ages ranging from 18 to 68 years. Two identical instruments - one in Spanish and one in French - each consisting of three activities were administered to participants: a grammaticality judgment task testing the syntactic knowledge of argument realization; a rating task testing students' pragmatic knowledge of the structures; and Activity 3, an elicited dialogue completion task testing students' production of these structures in a more controlled environment.

The results from the main study indicated and confirmed the main hypothesis, namely the Interface Hypothesis, because the syntax-pragmatics interface constructions under investigation - null subjects, postverbal subjects, CLLDs in Spanish and subject dislocations, c'est clefts, CLLDs in French - were found to be indeed vulnerable; i. e. difficult to acquire and causing a delay in acquisition. Informants in both languages had difficulties with these structures in all areas: their syntax, discourse-appropriateness and production. These results also confirmed the hypothesis that the difficulties in acquisition do indeed stem from the interface itself rather than from the differences in languages: learners of both Spanish and French had similar challenges in acquiring these structures at the interface. Varying degrees of vulnerability were detected for the different structures: the degree of difficulty in acquisition was influenced by the syntax and discourse complexity of the constructions. Furthermore, the results showed that syntactic competence is not acquired before discourse-pragmatic competence as 
previously thought, most likely due to the fact that learners focus more on meaning than on form. Finally, some improvement across proficiency levels was detected for some structures.

Data collected from this original study (Work 2010) was newly analyzed for this paper, focusing exclusively on data from Activity 2, which investigated English-speaking learners' perceptions about various types of subject and object realization in French and Spanish. A rating task was selected in order to get a better understanding of the informants' intuitions about the syntactic and pragmatic appropriateness of the sentences containing different types of Spanish and French subjects and objects. Since differing degrees of vulnerability were detected in the original study and since this activity also contained the less-pragmatically complex constructions associated with subject and object realization (i. e. preverbal subjects and in situ objects in Spanish and subject clitics and in situ objects in French), the data from the ranking task (Activity 2) proved to be useful in order to gain a better understanding of the relative order of acquisition in terms of argument realization. In Spanish, preverbal, null, and postverbal subjects as well as in situ objects with preverbal subjects, in situ objects with null subjects, CLLD structures with null subjects and CLLD structures with postverbal subjects were investigated. In French, subject clitics, subject dislocations, and subject clefts as well as in situ objects with subject clitics, in situ objects with subject dislocations, CLLD structures with subject clitics and CLLD structures with subject clefts were studied.

\section{$3 \quad$ Results}

As previously explained, only the data from Activity 2, the rating task testing learners' pragmatic knowledge of subject and object realization, was re-analyzed. This activity consists of 14 tokens, each with a context and two grammatically correct follow-up sentences containing either two different types of subjects or objects, one of which being more felicitous than the other. Students were asked to rate the discourse-pragmatic appropriateness of each follow-up sentence on a Likert-scale ranging from -2 (totally unacceptable) to +2 (totally acceptable). Both sentences could be assigned the same rating. The example in (16) below stems from the French questionnaire (see Appendices A and B for Activity 2 in Spanish and French).

$$
\begin{array}{llllll}
\text { Pierre adore la physique? } & & & & & \\
\text { 'Pierre likes physics?' } & -2 & -1 & 0 & +1 & +2 \\
\text {-- Non, la physique, il la déteste. } & & & & & \\
\quad \begin{array}{l}
\text { No, physics, he hates it.' } \\
\text {-- Non, il déteste la physique. }
\end{array} & -2 & -1 & 0 & +1 & +2
\end{array}
$$

The token in (16) above, for instance, provides the informants with a question and two grammatically correct answers: one containing a subject dislocation, and one containing a subject clitic. Based on the context and the underlying information structure, the first option, the subject dislocation would be more felicitous.

\subsection{Spanish}

Activity 2 was created to test learners' intuitions about these structures, i. e. their perceptions about their appropriateness in given pragmatic contexts. In comparing two grammatically correct sentences they were asked to rate each sentence's discourse-appropriateness (see Appendix A for Activity 2 with all its tokens). 


\begin{tabular}{|l|l|l|l|l|l|}
\hline \multicolumn{2}{|l|}{} & Low interm. & High interm. & Advanced & NS \\
\hline Preverbal & Mean \% & 67.31 & 87.50 & 99.22 & $95.31 \%$ \\
subjects & Mean diff. (NS) & -28.00 & -7.81 & 3.91 & \\
& Sig. (NS) & $.002^{*}$ & .718 & .960 & \\
\hline Null sub- & Mean \% & 59.62 & 69 & 76.56 & $78.12 \%$ \\
jects & Mean diff. (NS) & -18.51 & -9.12 & -1.56 & \\
& Sig. (NS) & .253 & .797 & .999 & \\
\hline Postverbal & Mean \% & 25 & 47 & 87.50 & $78.12 \%$ \\
subjects & Mean diff. (NS) & -53.12 & -31.12 & 9.38 & \\
& Sig. (NS) & $.000^{*}$ & $.049^{*}$ & .878 & \\
\hline
\end{tabular}

Tab. 3: Spanish results from Activity 2 - syntactic \& pragmatic knowledge: Subject realization.

Table 3 above illustrates the percentage of discourse-appropriate use broken down by structure in a context that required the structure in question. The results indicate that learners do not differ significantly from NS when accepting null subjects in terms of their discourseappropriateness in null subject contexts. That is, all learners seem to have grasped the concept of null subjects being topics. However, low intermediate learners differ significantly from NS when accepting preverbal subjects $(\mathrm{p}=.002)$; low and high intermediate learners when accepting postverbal subjects (low $p=.000$; high $p=.049$ ). This suggests that the pragmatics of postverbal subjects is indeed more difficult for learners and that the syntax-pragmatics interface is in fact vulnerable. Looking at the overall percentages of discourse-appropriate use, it seems that preverbal subjects are most frequently correctly accepted, followed by null subjects, and then followed by postverbal subjects. The only exceptions are advanced learners who most frequently accept preverbal subjects, followed by postverbal subjects and then null subjects. This result confirms that postverbal subjects seem to be acquired some time between the high intermediate level and the advanced level and that the advanced learners in this study have acquired this structure. Finally, native speaker and advanced learners do not differ significantly in their interpretation of Spanish subjects. What is interesting to note, however, is the fact that native speaker averages are not $100 \%$ in terms of null and postverbal subjects and that advanced learners averages are slightly higher for preverbal and postverbal subjects (although not significant).

\footnotetext{
${ }^{*}$ The mean difference is significant at the 0.05 level.
} 


\begin{tabular}{|l|l|l|l|l|l|}
\hline \multicolumn{2}{|l|}{} & Low interm. & High interm. & Advanced & NS \\
\hline Preverbal & Mean \% & 89.42 & 97.00 & 96.88 & $100 \%$ \\
subject & Mean diff. (NS) & -10.58 & -3.00 & -3.12 & \\
+ VO & Sig. (NS) & .329 & .963 & .965 & \\
\hline Null subject & Mean \% & 73.08 & 97.00 & 95.31 & $100 \%$ \\
+ VO & Mean diff. (NS) & -26.92 & -3.00 & -4.69 & \\
& Sig. (NS) & $.002^{*}$ & .977 & .932 & \\
\hline CLLD w/ & Mean \% & 50.00 & 67.00 & 62.50 & $81.25 \%$ \\
null subjects & Mean diff. (NS) & -31.25 & -14.25 & -18.75 & \\
& Sig. (NS) & $.013^{*}$ & .489 & .302 & \\
\hline CLLD w/ & Mean \% & 29.81 & 32 & 42.19 & $50 \%$ \\
postv. sub- & Mean diff. (NS) & -20.19 & -18.00 & -7.81 & \\
jects & Sig. (NS) & .112 & .189 & .843 & \\
\hline
\end{tabular}

Tab. 4: Spanish results from Activity 2 - syntactic \& pragmatic knowledge: Object realization.

Table 4 above shows the average percentage of discourse-appropriateness of object structures in a given context. In terms of object realization, learners and native speakers mostly do not differ significantly from each other: low intermediate learners are the only group differing significantly from NS in their acceptance of null subjects with in situ objects $(p=.002)$ and CLLD structures with null subjects $(\mathrm{p}=.013)$. This shows again the vulnerability of structures at the syntax-pragmatics interface. Looking at the overall percentages of appropriate use, all learners seem to most readily accept preverbal subjects with in situ objects, followed by null subjects with in situ objects; then CLLD structures with null subjects and lastly CLLD structures with postverbal subjects. The latter result is expected since postverbal subjects seem to be more difficult for learners and emerge sometime between the high intermediate and the advanced level. That, combined with a dislocation (CLLD) would make this structure extremely difficult for learners to interpret. Finally, Spanish native speakers' averages are well below $100 \%$ in terms of CLLD constructions.

\subsection{French}

Parallel to the Spanish questionnaire, Activity 2 in French was also constructed to test learners' pragmatic intuitions about the structures in question by ranking each grammatically correct sentence by its discourse appropriateness (see Appendix B for Activity 2 with all its tokens). The French results of this activity were as follows.

\footnotetext{
* The mean difference is significant at the 0.05 level.
} 


\begin{tabular}{|l|l|l|l|l|l|}
\hline \multicolumn{2}{|l|}{} & Low interm. & High interm. & Advanced & NS \\
\hline Subject cli- & Mean \% & 81.48 & 85.16 & 77.94 & $90 \%$ \\
tics & Mean diff. (NS) & -8.52 & -4.84 & -12.06 & \\
& Sig. (NS) & .765 & .944 & .555 & \\
\hline Subject & Mean \% & $73.61 \%$ & $79.69 \%$ & $89.71 \%$ & $87.50 \%$ \\
dislocation & Mean diff. (NS) & -13.89 & -7.81 & 2.21 & \\
& Sig. (NS) & .558 & .877 & .997 & \\
\hline Subject cleft & Mean \% & $57.41 \%$ & $58.59 \%$ & $69.12 \%$ & $85.00 \%$ \\
& Mean diff. (NS) & -27.59 & -26.41 & -15.88 & \\
& Sig. (NS) & $.034 *$ & $.042^{*}$ & .423 & \\
\hline
\end{tabular}

Tab. 5: French results from Activity 2 - syntactic \& pragmatic knowledge: Subject realization.

Table 5 above displays the average percentage of discourse-appropriate use of the different types of French subjects (i. e. subject clitics, subject dislocations, subject clefts) in a given context. In terms of rating their discourse-appropriateness, learners and NS do not differ significantly from each other when judging subject clitics or subject dislocations. In terms of subject clefts, both low and high intermediate learners differ significantly from NS (low $\mathrm{p}=.034$; high $\mathrm{p}=.042$ ), suggesting that sensitivity to the discourse-appropriateness of subject clefts evolves later than that of subject dislocations and subject clitics (i. e. between the high intermediate and advanced levels). This also indicates that the syntax-pragmatics interface is indeed vulnerable and the interface structures are difficult to acquire. Looking at the overall percentages of appropriate use, learners generally accept subject clitics most readily, followed by subject dislocations and finally subject clefts. What is interesting to note is that advanced learners accept subject dislocations most readily, followed by subject clitics and finally subject clefts. Finally, native speakers' ratings are less than $100 \%$ for subject clitics, dislocations, and clefts.

\begin{tabular}{|l|l|l|l|l|l|}
\hline \multicolumn{2}{|l|}{} & Low interm. & High interm. & Advanced & NS \\
\hline Subject cli- & Mean \% & 92.59 & 99.22 & 100 & $100 \%$ \\
tic + VO & Mean diff. (NS) & -7.41 & -.78 & .000 & \\
& Sig. (NS) & .505 & .999 & 1.000 & \\
\hline Subject & Mean \% & 79.63 & 87.50 & 89.71 & $85.00 \%$ \\
dislocation & Mean diff. (NS) & -5.37 & 2.50 & 4.71 & \\
+ VO & Sig. (NS) & .960 & .996 & .976 & \\
\hline CLLD w/ & Mean \% & 42.59 & 50.00 & 61.76 & $80.00 \%$ \\
subject clitic & Mean diff. (NS) & -37.41 & -30.00 & -18.24 & \\
& Sig. (NS) & $.000^{*}$ & $.004 *$ & .188 & \\
\hline CLLD w/ & Mean \% & $52.78 \%$ & $60.94 \%$ & $63.24 \%$ & $85.00 \%$ \\
cleft & Mean diff. (NS) & -32.22 & -24.06 & -21.76 & \\
& Sig. (NS) & $.045^{*}$ & .191 & .319 & \\
\hline
\end{tabular}

Tab. 6: French results from Activity 2 - syntactic \& pragmatic knowledge: Object realization.

Table 6 above showcases the average percentage of discourse-appropriate use of different types of French objects (i. e. subject clitics with canonical object, subject dislocation with canonical object, CLLD with subject clitic, CLLD with subject cleft) in a given context. The CLLD structures pose the greatest difficulty to French learners: Low and high intermediate

\footnotetext{
* The mean difference is significant at the 0.05 level.
} 
learners differ significantly from NS in terms of their interpretation of CLLD structures with subject clitics (low $\mathrm{p}=.000$; high $\mathrm{p}=.004$ ); and low intermediate learners in terms of CLLD structures with subject clefts $(\mathrm{p}=.045)$. Again, this shows that structures at the syntaxpragmatics interface are vulnerable and difficult to acquire. Generally when analyzing the overall percentages of discourse-appropriate use, learners are most comfortable with subject clitics and in situ objects followed by subject dislocations with in situ objects. CLLD with subject clitics seem to be more difficult to interpret than CLLDs with subject clefts. Finally, native speakers' ratings are less than $100 \%$ for subject dislocations + VO, and CLLD structures.

\section{Discussion}

\subsection{Spanish}

First and foremost, the data obtained from Activity 2 indicates that both subject and object realization in Spanish are difficult for English-speaking learners to acquire because their use is tied to the syntax-pragmatics interface. Thus, the IH generally seems to hold true. However, not all constructions at the syntax-pragmatics interface are equally vulnerable. Regarding Spanish subjects, low intermediate learners differ significantly from NS in their interpretation of preverbal subjects; low and high intermediate learners differ significantly from NS when accepting postverbal subjects in given contexts. Learners do not, however, differ significantly from NS in their interpretation of null subjects as topics. This indicates that null subjects are acquired very early in the acquisition, and that postverbal subjects are acquired the latest, some time between the high intermediate and advanced level. It seems that learners are able to very early on reset the null-subject parameter from their L1 to the [+ null subject] setting and that learners even at the low intermediate level have an understanding of the existence of null subjects. This analysis is supported by, for instance, Belletti and Leonini's (2004) finding that null subjects are acquired early. Spanish postverbal subjects are syntactically more complex in that they involve a word order alternation that differs from the canonical word order: learners have to put the subject after the verb. Another factor complicating the acquisition of postverbal subjects might be that they do not exist as such in English. Finally, postverbal subjects reverse the general association of subjects with topics in that they represent the focus of an utterance. This finding is supported by Dominguez (2007), who found that learners preferred SVO order over VOS in an acceptability judgment task. Moreover, Margaza and Bel (2006) and Montrul and Rodriguez Louro (2006) found in their studies null subjects to be less problematic than postverbal subjects for their learners of Spanish. Figure 1 below shows the average percentages of discourse-appropriate use per structure by proficiency level. 


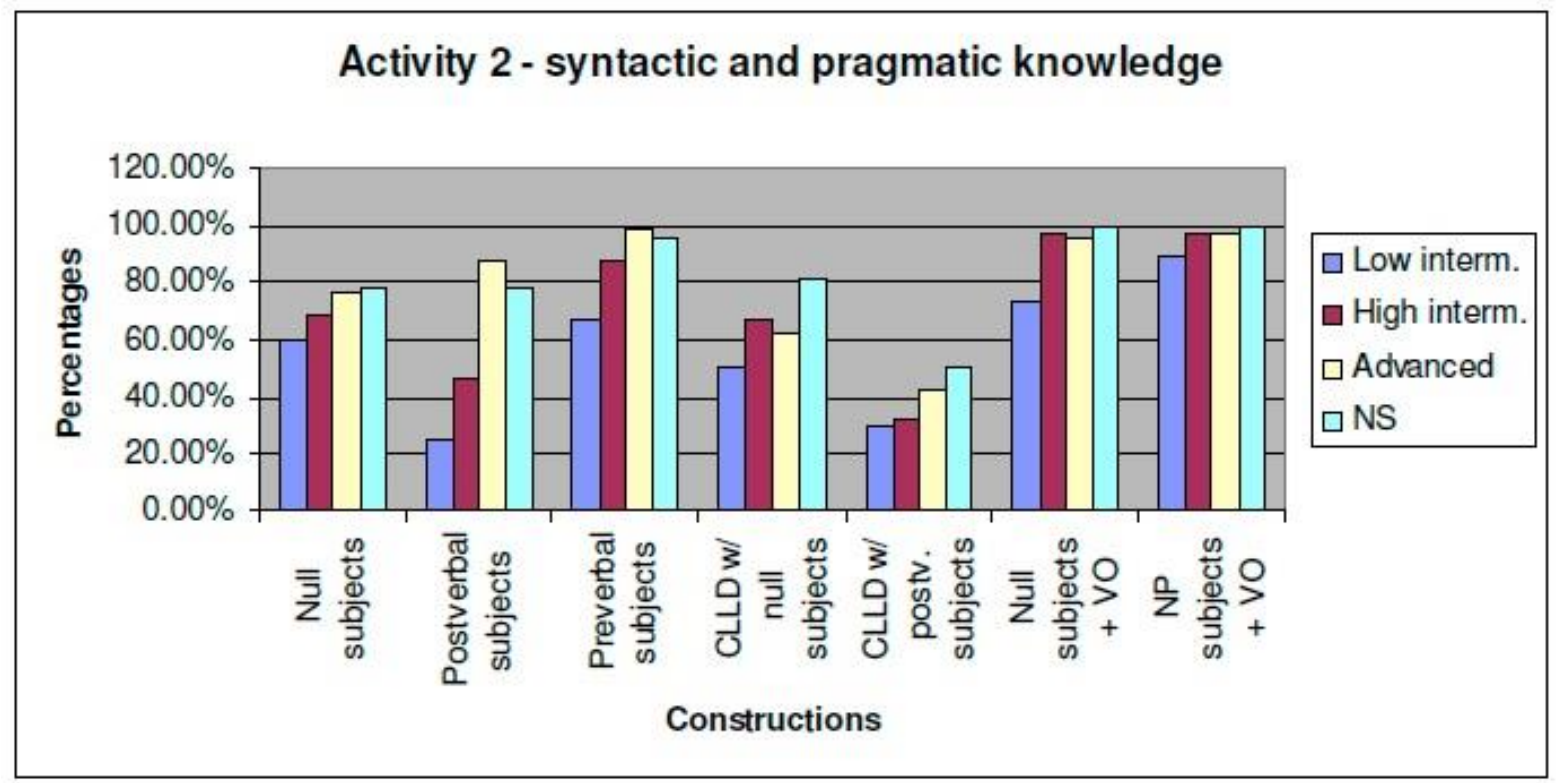

Figure 1: Spanish subject and object realization data.

More specifically, when looking at the percentage of appropriate use of all different subject types in Spanish, a general order of (felicitous) usage can be detected. All groups of learners interpret preverbal subjects most correctly, followed by null subjects, with postverbal subjects being interpreted the least correctly (see Figure 1). This order makes sense, in that preverbal subjects exist in English as well, and represent the unmarked subject position in SVO languages, and thus the discourse-new topic. Null subjects are also topical in nature, but represent discourse-old information. Moreover, null subjects are syntactically simple forms in that they involve the omission of a subject, but do not exist in the L1. Finally, postverbal subjects are focal which is discourse-pragmatically speaking the most difficult function of a subject. Plus, postverbal subject are syntactically very complex in Spanish as they reverse the typical SV word order and they do not exist in English. One interesting result and a small exception to this generalization is the fact that advanced learners reverse the aforementioned general order slightly. They interpret postverbal subjects more correctly than null subjects. This might be explained by the fact that - as mentioned above - postverbal subjects are acquired between the high intermediate and advanced proficiency levels and thus, as soon as they are acquired, learners have also mastered their discourse interpretation.

In terms of object realization, low intermediate learners are the only group of learners that differ significantly from NS, but only in their interpretation of in situ objects with null subjects and CLLD structures with null subjects. This is explainable by the fact that low intermediate learners rely on the unmarked word order and syntactic form for both subjects and objects, but have difficulties with all the other forms that involve opposition of general subject=topic and object=focus correlations. When looking at each group's percentages of appropriate acceptance of different types of Spanish objects, again a general order can be identified (see Figure 1). In situ objects with preverbal subjects are most correctly interpreted, followed by in situ objects with null subjects, followed by CLLD constructions with null subjects and finally followed by CLLD constructions with postverbal subjects. In situ objects are focal, in the unmarked, postverbal position, and exist in the L1. Thus, they are the easiest for learners to interpret. CLLD structures reverse that unmarked order and are non-focal objects. It is quite 
understandable that based on their discourse and syntactic complexity CLLD structures would be more difficult to interpret. CLLD structures involve a change in word order, where the object is placed in the left periphery of a sentence, together with an additional object clitic. CLLD structures become even more syntactically complex when they include a postverbal subject because the postverbal subject involves a separate word order alternation. In conclusion, it seems that the syntactic complexity as well as the discourse complexity of these structures in Spanish determines their order of acquisition and appropriate use.

\subsection{French}

In line with the Spanish results, French data from Activity 2 indicates that the IH holds true and that the syntax-pragmatics interface is indeed vulnerable since learners have difficulties with these interface structures. However, just like in Spanish, not all constructions at the syntax-pragmatics interface are equally vulnerable. When looking at the French subject data, learners only differ significantly from NS in terms of subject clefts (and only low and high intermediate learners). This is not surprising since subject clefts are not only syntactically complex structures (involving a cleft structure and relative clause), but also discoursepragmatically complex as they represent focal subjects. Judging from the data, subject clefts seem to have been acquired later, some time between the high intermediate and advanced level of proficiency. Figure 2 below shows the average percentages of discourse-appropriate use per structure by proficiency level.

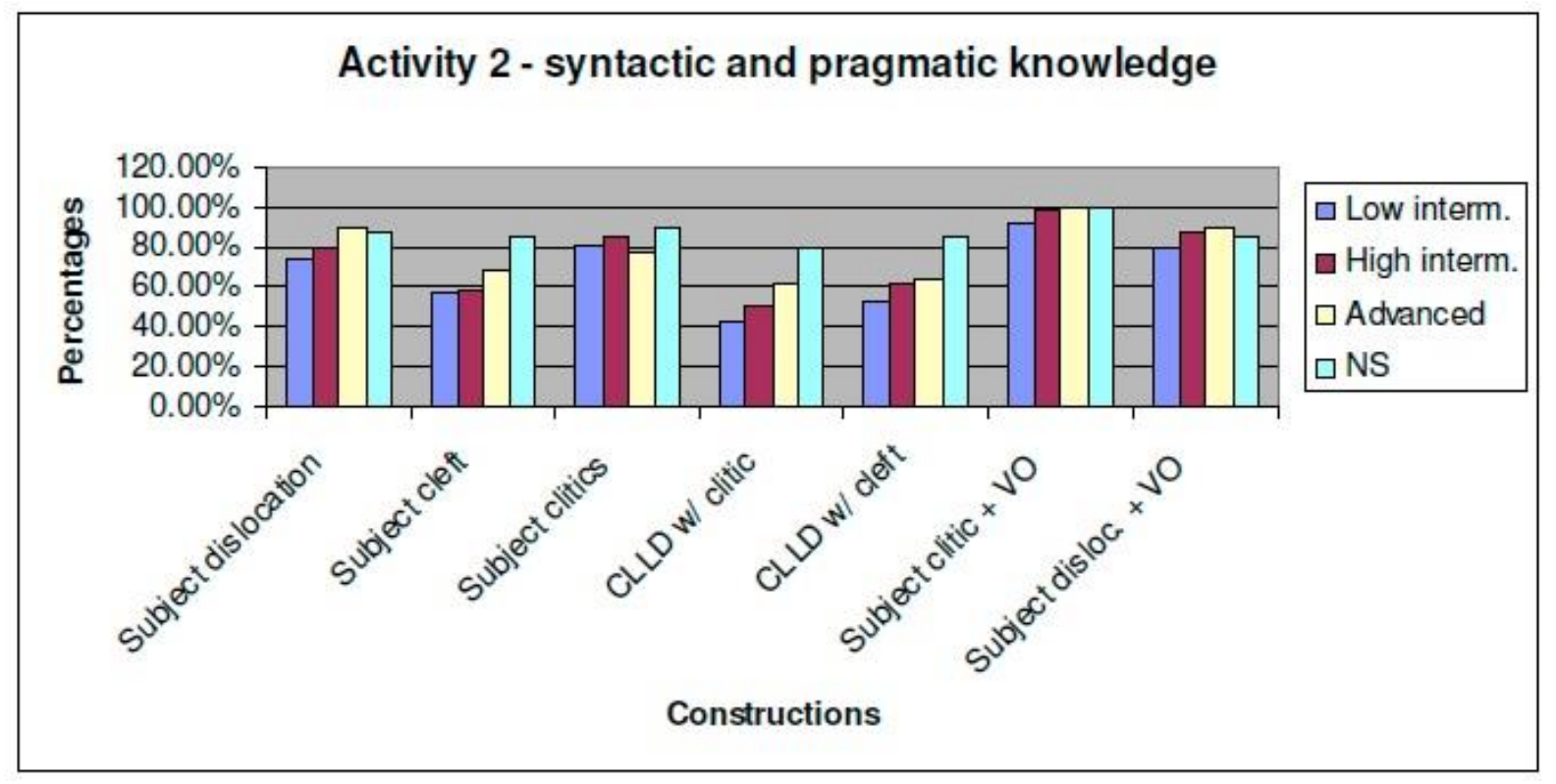

Figure 2. French subject and object realization data.

The data also reveal a trend or order in which the different types of subjects are accepted in French (see Figure 2). Generally learners interpret subject clitics most often correctly, followed by subject dislocations and finally, much less frequently, subject clefts. This is not surprising since subject clitics are topical in nature and are very similar to English subject pronouns in their interpretation. Subject dislocations, which become more and more frequent in the French language and very often substitute the simple use of a clitic, are interpreted correctly second most frequently by the learners. Clefted subjects are focal, which reverses the basic correspondence of subject $=$ topic and object $=$ focus. However, by using a cleft, the 
focal subject is converted into the predicate; from this perspective then, the focal element is not a subject anymore and the correspondence is not altered. But, learners are not usually trained in linguistics, and thus probably do not perceive a clefted subject in that way. Both subject dislocations and subject clefts exist in the L1 English. An interesting result and alteration of that suggested order is the fact that advanced learners use subject dislocations more often correctly then subject clitics. It seems to be that advanced learners have received a lot of NS input and have noticed and learned that French is becoming more and more topic prominent and that subject dislocations often replace the use of simple clitics.

In terms of object realization, learners differ only significantly from NS in their interpretation of CLLD structures (low intermediate learners for CLLD structures with subject clefts; low and high intermediate learners for CLLD structures with subject clitics). When looking at the percentages of appropriate interpretation, a general order of appropriate use can be detected (see Figure 2). All groups of learners interpret in situ objects with clitic subjects most often correctly followed by in situ objects with subject dislocations. Both of these structures contain objects in their unmarked, postverbal position functioning as the focus of the utterance, combined with subject clitics and subject dislocations, which are topics. These structures also exist in the L1 English. Learners interpret CLLD constructions with subject clefts third most accurately, with CLLD constructions with subject clitics being the least correctly interpreted, even though a similar left dislocation structure does exist in English. CLLD structures are in general discourse-pragmatically more complex since they reverse basic information structure. Instead of topical subjects and focal objects, French CLLD structures have topical (non-focal) objects.

\subsection{Other findings}

One interesting result was that the NS controls in both languages were not $100 \%$ for several structures. For the Spanish group, this included preverbal, null and postverbal subjects as well as CLLDs with null subjects and CLLDs with postverbal subjects. For the French group, this included subject clitics, dislocations and clefts as well as subject dislocations + VO, CLLDs with subject clitics and CLLDs with subject clefts.

Several factors might have influenced these results. For one, the data was collected in writing even though some structures, such as CLLDs and subject dislocations, are more colloquial and possibly more common in spoken language. Also, the contexts provided for all the activities are contexts that mimic spoken language. Thus, NS (and learners) might have been reluctant to use these more colloquial CLLD structures and subject dislocations in writing. It might also be that the contexts that were created for the instrument simply did not warrant the use of CLLD structures in both languages, for example. Or, these CLLD structures might not be used as frequently. Furthermore, since the coding for Activity 2 was based on NS's average judgments, this might have had an impact on the lower than $100 \%$ scores for the NS. Finally, the results may have been influenced by all of the native speakers recruited for the study living in the US for many years. 


\section{Conclusion}

Even though French and Spanish are two languages with different and complex relationships between syntactic structures and their discourse interpretation, learners seem to have similar difficulties acquiring subject and object realization. More specifically, the data from Activity 2 shows that topical subjects, focal subjects and dislocated topicalized objects are difficult in language acquisition regardless of the degree of similarity between the L1 and the L2. Consequently, it seems that interfaces in general are vulnerable in acquisition and that this vulnerability does not stem from the different discourse mappings between L1 and L2. Thus, in line with the original study, this study also confirms that the IH holds true: structures at the syntax-discourse interface are indeed more vulnerable and more difficult to acquire, resulting in a delay. However, advanced learners in both languages do not differ significantly from NS suggesting that, even though structures at the syntax-pragmatics interface cause delays in acquisition, they are eventually acquired and do not remain deficient. Furthermore, differing degrees of vulnerability were attested depending on the syntactic and discourse-pragmatic complexity of the structures. In terms of L2 acquisition of these structures, data from this study helps to pinpoint when these more difficult syntax-pragmatics interface structures are acquired. In Spanish, postverbal subjects are acquired between the high intermediate and advanced levels; null subjects + in situ objects and CLLDs with null subjects between low and high intermediate levels. In French, subject clefts are acquired between high intermediate and advanced levels; CLLDs with clefts between the low and high intermediate levels and CLLDs with clitics between the high intermediate and advanced levels. This result clearly shows that focal subjects and topical objects are difficult to acquire and need to be explicitly taught in Spanish and French languages classes. Moreover, learners seem to follow the same crosslinguistic general order when correctly accepting the discourse-appropriateness of these structures: Topical subjects are interpreted more often correctly than focal ones; Focal objects are more correctly interpreted than non-focal objects - irrespective of their different syntactic realizations in either language. This general order for subjects is modified slightly by the advanced learners in both languages. Advanced learners in Spanish interpret postverbal subject contexts more frequently correctly than null subject contents; French learners interpret subject dislocation contexts more frequently correctly than subject clitic contexts. Due to the amount of input they have received and the advanced grammar and stylistic classes they have taken, Spanish advanced learners have acquired postverbal subjects and their interpretation and can now more correctly use them. Along the same lines, French advanced learners have acquired - through plentiful input and advanced grammar and stylistics classes - that French is becoming more and more topic-prominent and that subject dislocations often replace the use of simple subject clitics.

\section{References}

Antes, Theresa (1995): "The move towards topic prominence in spoken French: Grammatical and pedagogical repercussions". Michigan Academician 27(4): 503-514.

Argyri, Efrosyni/Sorace, Antonella (2007): "Crosslinguistic influence and language dominance in older bilingual children". Bilingualism: Language and Cognition 10(1): 79-99.

Ashby, William (1988): "The syntax, pragmatics, and sociolinguistics of left- and right dislocations in French". Lingua 75: 203-229. 
Belletti, Adriana/Leonini, Celeste (2004): "Subject inversion in L2 Italian". In: Foster-Cohen, Susan et al. (eds.): EUROSLA Yearbook: Volume 4. Amsterdam, Benjamins: 95-118.

Bos, Petra/Hollebrandse, Bart/Sleeman, Petra (2004): "The pragmatics-syntax and the semantics-syntax interface in acquisition". International Review of Applied Linguistics in Language Teaching 42(2): 101-110.

Bruhn-Garavito, Joyce/Montrul, Silvina A. (1996): "Verb movement and clitic placement in French and Spanish as a second language". In: Stringfellow, Andy et al. (eds.): Proceedings of the 20th Annual Boston University Conference on Language Development, I-II. Somerville, MA, Cascadilla Press: 123-134.

Casielles-Suárez, Eugenia (2004): The syntax-information structure interface. Evidence from Spanish and English. New York: Routledge.

Contreras, Heles (1976): A theory of word order with special reference to Spanish. Amsterdam, New York: North Holland.

Dominguez, Laura (2007): "The L2 acquisition of Spanish focus: A case of incomplete and divergent Grammars". In: Baauw, Sergio/Van Kampen, Jacqueline/Pinto, Manuela (eds.): The Acquisition of Romance Languages. Selected Papers from The Romance Turn II. Utrecht, LOT: 45-57.

Dominguez, Laura/Arche, María (2008): "Optionality in L2 grammars: The acquisition of SV/VS contrast in Spanish". In: Chan, Harvey/Jacob, Heather/Kapia, Enkeleida Kapia (eds.): Proceedings of BUCLD 32. Somerville, MA: Cascadilla Press: 96-107.

Erteschik-Shir, Nomi (2007): Information Structure: The Syntax-Discourse Interface. Oxford: Oxford University Press.

Ferdinand, Astrid (2002): "Acquisition of syntactic topic marking in L2 French". In: Broekhuis, Hans/Fikkert, Paula (eds.): Linguistics in the Netherlands 2002. Amsterdam: John Benjamins: $49-59$.

Gundel, Jeanette K. (1988): The role of topic and comment in linguistic theory. New York: Garland.

Halliday, Michael A. K. (1967): "Notes on transitivity and theme in English: Part II". Journal of Linguistics 3: 199-244.

Hertel, Tammy J. (2003): "Lexical and discourse factors in the second language acquisition of Spanish word order". Second Language Research 19(4): 273-304.

Hollerbach, Wolf (1994): The syntax of contemporary French: A pedagogical handbook and reference grammar. Lanham: University Press of America.

Hughes, Mary/Allen, Shanley (2006): "A discourse-pragmatic analysis of subject omission in child English". In: Bamman, David/Magnitskaia, Tatiana/Zaller, Colleen (eds.): hughes . Somerville, MA: Cascadilla Press: 293-304.

Hulk, Aafke/Müller, Natascha (2000): "Bilingual first language acquisition at the interface between syntax and pragmatics". Bilingualism: Language and Cognition 3(3): 227-244.

Lardiere, Donna (2011): "Who is the Interface Hypothesis about"? Linguistic Approaches to Bilingualism 1(1): 48-53.

Lozano, Cristóbal (2006): "Focus and split-intransitivity: The acquisition of word order alternations in non-native Spanish". Second Language Research 22: 145-187.

Margaza, Panagiota/Bel, Aurora (2006): "Null subjects at the syntax-pragmatics interface: Evidence from Spanish interlanguage of Greek speakers". In: O'Brien, Mary Grantham/Shea, Christine Shea/Archibald, John (eds.): Proceedings of the 8th Generative Ap- 
proaches to Second Language Acquisition Conference (GASLA). Somerville, MA: Cascadilla Proceedings Project: 88-97.

Montrul, Silvina (2004): "Subject and object expression in Spanish heritage speakers: A case of morphosyntactic convergence". Bilingualism: Language and Cognition 7(2): 125-142.

Montrul, Silvina/Rodríguez Louro, Celeste (2006): "Beyond the syntax of the Null Subject Parameter: A look at the discourse-pragmatic distribution of null and overt subjects by L2 learners of Spanish". In: Torrens, Vincent/Escobar, Linda (eds.): The Acquisition of Syntax in Romance Languages. Amsterdam, Philadelphia: Benjamins: 401-418.

Müller, Natascha/Hulk, Aafke (2001): "Crosslinguistic influence in bilingual language acquisition: Italian and French as recipient languages". Bilingualism: Language and Cognition 4(1): 1-21.

Paradis, Johanne/Navarro, Samuel (2003): "Subject realization and crosslinguistic interference in the bilingual acquisition of Spanish and English: What is the role of the input"? Journal of Child Language 30(2): 371-393.

Pinto, Manuela (2006): "Subject pronouns in bilinguals: Interference or maturation"? In: Torrens, Vincent/Escobar, Linda (eds.): The Acquisition of Syntax in Romance Languages. Amsterdam, John Benjamins: 331-350.

Rothman, Jason/Guijarro-Fuentes, Pedro (2012): "Linguistic interfaces and language acquisition in childhood: Introduction to the Special Issue". First Language 32(3): 3-16.

Schaeffer, Jeannette (2000): Direct object scrambling and clitic placement: Syntax and pragmatics. Amsterdam: John Benjamins.

Serratrice, Ludovica/Sorace, Antonella/Paoli, Sandra (2004): "Crosslinguistic influence at the syntax-pragmatics interface: Subject and objects in English-Italian bilingual and monolingual acquisition". Bilingualism: Language and Cognition, 7(3): 183-205.

Slabakova, Roumyana/Kempchinsky, Paula/Rothman, Jason (2012): "Clitic-doubled left dislocation and focus fronting in L2 Spanish: A case of successful acquisition at the syntaxdiscourse interface". Second Language Research 28(3): 319-343.

Sleeman, Petra (2004): "Guided learners of French and the acquisition of emphatic constructions". International Review of Applied Linguistics in Language Teaching 42(2): 129-151.

Sorace, Antonella (2003): "Near-nativeness". In: Doughty, Catherine J./Long, Michael H. (eds.): The handbook of second language acquisition. Oxford, Blackwell: 130-151.

Sorace, Antonella (2011): "Pinning down the concept of "interface" in bilingualism". Linguistic Approaches to Bilingualism 1(1): 1-33.

Sorace, Antonella/Filiaci, Francesca (2006): "Anaphora resolution in near-native speakers of Italian". Second Language Research 22(3): 339-368.

Sorace, Antonella/Serratrice, Ludovica (2009): "Internal and external interfaces in bilingual language development: Beyond structural overlap". International Journal of Bilingualism 13(2): 195-210.

Tedeschi, Roberta (2009): Acquisition at the interfaces: a case study on object clitics in Early Italian. Utrecht, Netherlands: University of Utrecht.

Tsimpli, Ianthi/Sorace, Antonella (2006): "Differentiating interfaces: L2 performance in syntax-semantics and syntax-discourse phenomena". In: Bamman, David/Magnitskaia, Tatiana/Zaller, Colleen (eds.): BUCLD 30 Proceedings. Somerville, MA: Cascadilla Press: 653-664. 
Tsimpli, Ianthi et. al. (2004): "First language attrition and syntactic subjects: A study of Greek and Italian near-native speakers of English". International Journal of Bilingualism 8(3): 257-277.

van Valin, Robert D. (1999): "A typology of the interaction of focus structure and syntax". In: Raxilina, Ekaterina/Testelec, Jakov (eds.): Typology and the theory of language: From description to explanation. Moscow: Languages of Russian Culture: 511-524.

Vallduví, Enric/Engdahl, Elisabet (1998): "The linguistic realisation of information packaging". Linguistics 34: 459-519.

White, Lydia (2011): "Second language acquisition at the interfaces". Lingua 121: 577-590.

Work, Nicola (2010): Argument realization in French and Spanish second language acquisition: A view from the syntax-pragmatics interface. Saarbrücken: LAP Publishing.

Zagona, Karen (2002): The syntax of Spanish. Cambridge: Cambridge University Press. 


\section{Appendix A \\ Spanish Instrument}

\section{ACTIVIDAD 2}

\section{Instructions:}

Speakers of a language seem to develop a "feel" for what is a possible sentence, even when they have never been explicitly taught the particular rule. For example, in English, you might feel that the first sentence below sounds possible whereas the second one does not.

John is likely to win the race. John is probably to win the race.

In this activity you will read a question or statement in Spanish as well as two possible follow-up sentences, printed in bold. Please read all the sentences with regular intonation without emphasizing any particular element. You will then be asked to tell whether you think each of the two sentences is possible or impossible in Spanish. Beside each sentence, you will see a scale of five numbers. Circle only ONE of the numbers for EACH of the follow-up sentences. You may assign the same number for both sentences if you feel they are equally acceptable. Please use the numbers as follows:

$\begin{array}{lllll}-2 & -1 & 0 & +1 & +2 \\ \text { completely } & \text { somewhat } & \text { unable } & \text { somewhat } & \text { completely } \\ \text { impossible } & \text { impossible } & \text { to decide } & \text { possible } & \text { possible }\end{array}$

\section{EXAMPLE:}

A. ¿Quieres comer conmigo?

-- No tengo hambre.

-- No tengo mi libro.

$\begin{array}{lllll}-2 & -1 & 0 & +1 & \underline{+2} \\ -2 & -1 & 0 & +1 & +2\end{array}$

Native speakers of Spanish often have different feelings about such sentences, so don't worry about having a right or wrong intuition about these sentences. Simply respond based upon your impressions.

1. ¿Qué hacen Pedro y Pablo?

-- Pedro es mi amigo.

-- Pedro estudia en la biblioteca.

$\begin{array}{lllll}-2 & -1 & 0 & +1 & +2 \\ -2 & -1 & 0 & +1 & +2\end{array}$

2. ¿A Pedro le gusta la física?

-- No, la física la odia.

-- No, odia la física.

$\begin{array}{lllll}-2 & -1 & 0 & +1 & +2 \\ -2 & -1 & 0 & +1 & +2\end{array}$

3. ¿Sabes algo de Elisa?

-- Sí, me llama todas las semanas.

-- Sí, ella me llama todas las semanas.

$\begin{array}{lllll}-2 & -1 & 0 & +1 & +2 \\ -2 & -1 & 0 & +1 & +2\end{array}$




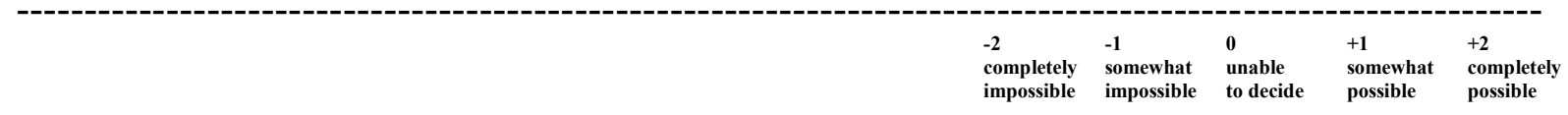

4. ¿Quién llega mañana?

-- Mañana llega María.

-- María llega mañana.

$\begin{array}{lllll}-2 & -1 & 0 & +1 & +2 \\ -2 & -1 & 0 & +1 & +2\end{array}$

5. ¿Qué necesitan Pedro y Ana?

-- El carro lo necesita Ana.

-- Ana necesita el carro.

$\begin{array}{lllll}-2 & -1 & 0 & +1 & +2 \\ -2 & -1 & 0 & +1 & +2\end{array}$

6. ¿Quién busca la revista?

-- Elisa busca la revista.

-- La revista la busca Elisa.

$\begin{array}{lllll}-2 & -1 & 0 & +1 & +2 \\ -2 & -1 & 0 & +1 & +2\end{array}$

7. ¿Qué fecha es hoy?

-- Hoy es martes.

-- Hoy es el nueve de enero.

$\begin{array}{lllll}-2 & -1 & 0 & +1 & +2\end{array}$

$\begin{array}{lllll}-2 & -1 & 0 & +1 & +2\end{array}$

8. ¿Hasta qué hora duermen tus amigos?

-- Miguel duerme hasta las once.

-- Hasta las once duerme Miguel.

$\begin{array}{lllll}-2 & -1 & 0 & +1 & +2\end{array}$

$\begin{array}{lllll}-2 & -1 & 0 & +1 & +2\end{array}$

9. ¿Qué busca Marco?

-- EI libro lo busca.

-- Busca el libro.

$\begin{array}{lllll}-2 & -1 & 0 & +1 & +2 \\ -2 & -1 & 0 & +1 & +2\end{array}$

10. Pablo habla con su hermano y le dice:

-- Me gusta tu perro.

-- Me gusta su perro.

$\begin{array}{lllll}-2 & -1 & 0 & +1 & +2\end{array}$

$\begin{array}{lllll}-2 & -1 & 0 & +1 & +2\end{array}$

11. Acabo de ver a Elisa y a Tomás.

-- Ella se va de vacaciones, pero él no puede.

-- Se va de vacaciones, pero él no puede.

$\begin{array}{lllll}-2 & -1 & 0 & +1 & +2\end{array}$

$\begin{array}{lllll}-2 & -1 & 0 & +1 & +2\end{array}$

12. ¿Quién prepara el flan?

-- El flan lo prepara Ana.

-- Ana prepara el flan.

$\begin{array}{lllll}-2 & -1 & 0 & +1 & +2\end{array}$

$\begin{array}{lllll}-2 & -1 & 0 & +1 & +2\end{array}$

13. ¿Quién corre por la mañana?

-- Luisa corre por la mañana.

-- Por la mañana corre Luisa.

$\begin{array}{lllll}-2 & -1 & 0 & +1 & +2 \\ -2 & -1 & 0 & +1 & +2\end{array}$

14. Tu amiga es muy activa.

-- Sí, hace mucho ejercicio.

-- Sí, es muy sedentaria.

$\begin{array}{lllll}-2 & -1 & 0 & +1 & +2 \\ -2 & -1 & 0 & +1 & +2\end{array}$


15. A María no le gusta la música de Thalía, ¿verdad?

-- No, la música de Thalía la detesta.

-- No, detesta la música de Thalía.

$\begin{array}{lllll}-2 & -1 & 0 & +1 & +2 \\ -2 & -1 & 0 & +1 & +2\end{array}$

16. ¿María y Pedro entregan siempre la tarea a tiempo?

-- Él siempre la entrega a tiempo, pero María no.

-- Siempre la entrega a tiempo, pero María no.

$\begin{array}{lllll}-2 & -1 & 0 & +1 & +2\end{array}$

$\begin{array}{lllll}-2 & -1 & 0 & +1 & +2\end{array}$

17. ¿Quién escribió la novela?

-- La novela fue escrita por Cervantes.

-- Cervantes escribió la novela.

$\begin{array}{lllll}-2 & -1 & 0 & +1 & +2\end{array}$

$\begin{array}{lllll}-2 & -1 & 0 & +1 & +2\end{array}$

18. ¿Qué traen María y Marcos a la fiesta?

-- María trae el pastel.

-- El pastel lo trae María.

$\begin{array}{lllll}-2 & -1 & 0 & +1 & +2\end{array}$

$\begin{array}{lllll}-2 & -1 & 0 & +1 & +2\end{array}$

19. ¿A Pablo le gustan mucho los deportes, ¿verdad?

-- Sí, juega al béisbol todos los días.

-- Sí, él juega al béisbol todos los días.

$\begin{array}{llllll}-2 & -1 & 0 & +1 & +2\end{array}$

$\begin{array}{lllll}-2 & -1 & 0 & +1 & +2\end{array}$

20. ¿Qué trae Ana para la fiesta?

-- Trae el postre.

-- El postre lo trae.

$\begin{array}{llllll}-2 & -1 & 0 & +1 & +2\end{array}$

$\begin{array}{llllll}-2 & -1 & 0 & +1 & +2\end{array}$

21. ¿A qué hora salen tus amigas?

-- Paula sale a las cinco.

-- A las cinco sale Paula.

$\begin{array}{lllll}-2 & -1 & 0 & +1 & +2\end{array}$

$\begin{array}{lllll}-2 & -1 & 0 & +1 & +2\end{array}$

22. María habla con el Presidente de México y le dice.

-- Admiro su trabajo.

-- Admiro tu trabajo.

$\begin{array}{lllll}-2 & -1 & 0 & +1 & +2\end{array}$

$\begin{array}{lllll}-2 & -1 & 0 & +1 & +2\end{array}$ 


\section{Appendix B \\ French Instrument}

\section{ACTIVITÉ 2}

\section{Instructions :}

Speakers of a language seem to develop a "feel" for what is a possible sentence, even when they have never been explicitly taught the particular rule. For example, in English, you might feel that the first sentence below sounds possible whereas the second one does not.

John is likely to win the race.

John is probably to win the race

In this activity you will read a question or statement in French as well as two possible follow-up sentences, printed in bold. Please read all the sentences with regular intonation without emphasizing any particular element. You will then indicate to what degree you think each of the two follow-up sentences is possible or impossible in French. Beside each sentence, you will see a scale of five numbers. Circle only ONE of the numbers for EACH of the follow-up sentences. You may assign the same number for both sentences if you feel they are equally acceptable. Please use the numbers as follows:

$\begin{array}{lllll}-2 & -1 & 0 & +1 & +2 \\ \text { completely } & \text { somewhat } & \text { unable } & \text { somewhat } & \text { completely } \\ \text { impossible } & \text { impossible } & \text { to decide } & \text { possible } & \text { possible }\end{array}$

EXAMPLE:

A. Marie aime étudier.

-- Elle étudie souvent.

-- Elle adore étudier.

$\begin{array}{lllll}-2 & -1 & 0 & \underline{+1} & +2 \\ -2 & -1 & 0 & +1 & \underline{+2}\end{array}$

Native speakers of French often have different feelings about such sentences, so don't worry about having a right or wrong intuition about these sentences. Simply respond based upon your impressions.

1. Que fait Pierre?

-- Il est mon ami.

-- Il étudie à la bibliothèque.

$\begin{array}{lllll}-2 & -1 & 0 & +1 & +2\end{array}$

2. Pierre adore la physique?

-- Non, la physique, il la déteste.

-- Non, il déteste la physique.

$\begin{array}{lllll}-2 & -1 & 0 & +1 & +2\end{array}$

3. Quelle est la spécialisation d'Elise?

-- Elise, elle étudie la chimie organique. $\quad \begin{array}{llllll}-2 & -1 & 0 & +1 & +2\end{array}$

$\begin{array}{lllllll}-- & \text { Elle étudie la chimie. } & -2 & -1 & 0 & +1 & +2\end{array}$ 
4. Qui arrive demain?

-- C'est Paul qui arrive demain.

-- Paul, il arrive demain.

5. Que cherchent Pierre et Anne?

-- Anne, elle cherche la clé.

-- La clé, c'est Anne qui la cherche.

6. Qui cherche la revue?

-- Pierre, il cherche la revue.

-- La revue, c'est Pierre qui la cherche.

7. Quelle est la date?

-- C'est mardi.

-- C'est le neuf janvier.

8. Tes amis dorment jusqu'à quelle heure ?

-- C'est Marcel qui dort jusqu'à midi.

-- Marcel, il dort jusqu'à midi.

9. Que cherche Marc ?

-- Le livre, il le cherche.

-- Il cherche le livre.

10. Pierre parle à son petit frère. Il lui dit:

-- J'adore ton chien.

-- J'adore votre chien.

$-2$

$-2$

11. Je viens de voir Élise et Marcel.

-- Élise, elle va en vacances.

-- Elle va en vacances.

12. Qui prépare le flan?

-- Le flan, c'est Amélie qui le prépare.

-- Amélie, elle prépare le flan.

13. Qui fait toujours du jogging?

-- C'est Louise qui fait toujours du jogging.

-- Louise, elle fait toujours du jogging.

14. Elise est très sportive.

-- Elle fait de l'exercice.

-- Elle est sédentaire.

$\begin{array}{lllll}-1 & 0 & +1 & +2 & \\ -2 & -1 & 0 & +1 & +2\end{array}$

$\begin{array}{lllll}-2 & -1 & 0 & +1 & +2\end{array}$

$\begin{array}{lllll}-2 & -1 & 0 & +1 & +2\end{array}$

$\begin{array}{lllll}-2 & -1 & 0 & +1 & +2\end{array}$

$\begin{array}{llllll}-2 & -1 & 0 & +1 & +2\end{array}$

$\begin{array}{lllll}-2 & -1 & 0 & +1 & +2\end{array}$

$\begin{array}{lllll}-2 & -1 & 0 & +1 & +2\end{array}$

$\begin{array}{lllll}-2 & -1 & 0 & +1 & +2\end{array}$

$\begin{array}{lllll}-2 & -1 & 0 & +1 & +2\end{array}$

$\begin{array}{lllll}-2 & -1 & 0 & +1 & +2\end{array}$

$\begin{array}{llllll}-2 & -1 & 0 & +1 & +2\end{array}$

$\begin{array}{lllll}-2 & -1 & 0 & +1 & +2\end{array}$

$\begin{array}{llllll}-2 & -1 & 0 & +1 & +2\end{array}$

$\begin{array}{llllll}-2 & -1 & 0 & +1 & +2\end{array}$

$\begin{array}{lllll}-2 & -1 & 0 & +1 & +2\end{array}$

$\begin{array}{lllll}-2 & -1 & 0 & +1 & +2\end{array}$

$\begin{array}{lllll}-2 & -1 & 0 & +1 & +2\end{array}$

$\begin{array}{lllll}-2 & -1 & 0 & +1 & +2\end{array}$

$\begin{array}{llllll}-2 & -1 & 0 & +1 & +2\end{array}$ $\begin{array}{lllll}-2 & -1 & 0 & +1 & +2 \\ -2 & -1 & 0 & +1 & +2\end{array}$ 


$\begin{array}{lllll}-2 & -1 & 0 & +1 & +2 \\ \text { completely } & \text { somewhat } & \text { unable } & \text { somewhat } & \text { completely } \\ \text { impossible } & \text { impossible } & \text { to decide } & \text { possible } & \text { possible }\end{array}$

15. Marie préfère la musique d'IAM, n'est-ce pas?

-- Non, la musique d'IAM, elle la déteste.

$\begin{array}{lllll}-2 & -1 & 0 & +1 & +2\end{array}$

-- Non, elle déteste la musique d'IAM.

$\begin{array}{lllll}-2 & -1 & 0 & +1 & +2\end{array}$

16. Marie et Loïc remettent leur composition toujours à l'heure ?

-- Loïc, il la remet toujours à l'heure, mais pas Marie. $\begin{array}{llllll}-2 & -1 & 0 & +1\end{array}$

-- Il la remet toujours à l'heure, mais pas Marie. $\quad \begin{array}{llllll}-2 & -1 & 0 & +1\end{array}$

17. Qui enseigne le français à l'université ?

$\begin{array}{lllllll}-- & \text { Le français est enseigné par des professeurs. } & -2 & -1 & 0 & +1 & +2\end{array}$

$\begin{array}{lllllll}-- & \text { Des professeurs enseignent le français. } & -2 & -1 & 0 & +1 & +2\end{array}$

18. Qu'est-ce que Marc et Marie amènent à la fête ?

-- Marie, elle amène le gâteau.

-- Le gâteau, c'est Marie qui l'amène.

$\begin{array}{lllll}-2 & -1 & 0 & +1 & +2\end{array}$

$\begin{array}{lllll}-2 & -1 & 0 & +1 & +2\end{array}$

19. Pierre aime le sport, n'est-ce pas ?

-- Oui, il joue au baseball chaque jour.

-- Oui, Pierre, il joue au baseball chaque jour.

$\begin{array}{lllll}-2 & -1 & 0 & +1 & +2\end{array}$

$\begin{array}{lllll}-2 & -1 & 0 & +1 & +2\end{array}$

20. Que prépare Élise pour la fête?

-- Le dessert, elle le prépare.

-- Elle prépare le dessert.

$\begin{array}{lllll}-2 & -1 & 0 & +1 & +2\end{array}$

$\begin{array}{lllll}-2 & -1 & 0 & +1 & +2\end{array}$

21. Tes amis sortent à quelle heure?

-- C'est Marie qui sort à 10 heures.

-- Marie, elle sort à 10 heures.

$\begin{array}{lllll}-2 & -1 & 0 & +1 & +2\end{array}$

$\begin{array}{lllll}-2 & -1 & 0 & +1 & +2\end{array}$

22. Marie parle au Président de la France. Elle lui dit :

-- J'admire votre travail.

-- J'admire ton travail.

$\begin{array}{lllll}-2 & -1 & 0 & +1 & +2\end{array}$

$\begin{array}{lllll}-2 & -1 & 0 & +1 & +2\end{array}$ 